\title{
Assessment of Striga gesnerioides (Willd.) Resistance and Genetic Characterization of Forty-Six Cowpea (Vigna unguiculata (L.) Walp.) Genotypes in Ghana
}

\author{
Peter Haruna, ${ }^{1}$ Aaron T. Asare ${ }^{\mathbb{D}},{ }^{1}$ and Francis Kusi ${ }^{2}$ \\ ${ }^{1}$ Department of Molecular Biology and Biotechnology, University of Cape Coast, Cape Coast, Ghana \\ ${ }^{2}$ Savannah Agricultural Research Institute (SARI), P.O. Box 46, Manga Station, Bawku, Ghana \\ Correspondence should be addressed to Aaron T. Asare; aasare@ucc.edu.gh
}

Received 18 February 2020; Revised 13 May 2020; Accepted 2 June 2020; Published 23 June 2020

Academic Editor: Maria Serrano

Copyright (c) 2020 Peter Haruna et al. This is an open access article distributed under the Creative Commons Attribution License, which permits unrestricted use, distribution, and reproduction in any medium, provided the original work is properly cited.

\begin{abstract}
The parasitic weed, Striga gesnerioides, imposes physiological stress on cowpea (Vigna unguiculata (L.) Walp.) resulting in significant yield loss in the regions of northern Ghana. This warranted identification of resistant cowpeas for sustainable production. The current work aim was to identify Striga-resistant cowpea genotypes and assess their genetic relatedness. Forty-six (46) cowpea genotypes were screened in pots for their reaction to Striga samples obtained from the upper east, upper west, and northern regions of Ghana and validated with C42-2B and 61R-M2 markers involving DNA amplification by PCR assay. Sixteen polymorphic SSR primer pairs were used to assess genetic relatedness among 46 cowpea genotypes. Data were analyzed with PowerMarker V. 3.25 and a dendrogram was generated with MEGA 4. On the whole, $65.2 \%$ of the cowpea genotypes had stable resistance to S. gesnerioides from the regions of northern Ghana and 34.8\% were susceptible. The C42-2B marker resolved as a single DNA band of 280 bp with segregation efficiency of $80 \%$ and 61R-M2 marker as double DNA bands of 320 bp and 380 bp with segregation efficiency of $60 \%$ associated with Striga resistance. Sixteen (16) polymorphic SSR primers distinguished all 46 cowpea genotypes into three clusters. Gene diversity ranged from 0.04 to 0.49 with an average of 0.29 . The average allele frequency is 0.78 , with a mean genetic diversity of 0.29 . Polymorphism information content (PIC) varied from 0.08 to 1.00 with an average of 0.55. Therefore, cowpeas with Striga resistance and other desirable traits can be evaluated and released as varieties for farmers to cultivate.
\end{abstract}

\section{Introduction}

Cowpea (Vigna unguiculata (L.) Walp.) is the second most important legume in the regions of northern Ghana, after groundnuts in terms of area under cultivation, quantity produced, and annual consumption [1]. Ghana is the fifth highest producer of cowpea in Africa [2] with an average of 143,000 MT produced annually on about 156,000 ha of land. There has been a projection that the rate of cowpea production for the period between 2010 and 2020 would increase by $11.1 \%$ [3]. However, cowpea production in the major cultivation regions of northern Ghana is constrained by both abiotic and biotic factors [4]. One of the major biotic constraints to cowpea productivity among small-holder and resource-poor farmers in the regions of northern Ghana is the attack by parasitic weed, Striga gesnerioides (Willd.) Vatke [5].

S. gesnerioides is a devastating obligate root hemiparasite that primarily parasitizes dicotyledonous species, including cowpea and other legumes [6,7]. Cowpea yield losses associated with $S$. gesnerioides infestations range from 83 to $100 \%[5,8]$. The degree of damage to cowpea caused by $S$. gesnerioides is as a result of the close parasitic association between the host cowpea and the parasitic weed. Seeds of $S$. gesnerioides in the soil germinate in response to specific stimulants produced by cowpea roots [9]. Haustoria developed by the parasites [10] are used to attach the roots and penetrate the vascular tissues to establish vascular connections with the host cowpea [11]. Water, minerals, and organic compounds (photosynthates) are drawn from the 
cowpea for the development of the parasite [12]. Several control strategies have been developed including cultural practices, the use of chemical control, and breeding for resistance [13]. Control strategies based on the use of herbicides are too expensive for low-input farming systems, whilst cultural practices are inefficient [14]. However, according to [15], host plant resistance has the potential to efficiently control the parasitic weed, which can be accessible to resource-poor farmers as well as environmentally friendly [5].

Seven races of S. gesnerioides have been identified based on host differential response and genetic diversity analysis within the cowpea growing regions of West Africa [16]. The races of Striga are designated as SG1 (Burkina Faso), SG2 (Mali), SG3 (Nigeria and Niger), SG4 and SG4z (Benin), SG5 (Cameroon), and SG6 (Senegal). However, the race of $S$. gesnerioides across the three regions of northern Ghana has not been confirmed. It is also unclear whether the S. gesnerioides in the northern Ghana is one of the known races in West Africa or a novel biotype. According to [17], race formation in cowpea-Striga association is largely a result of host-driving selection. Identification of race-specific responses in cowpea is relevant for the development of targetresistant genotypes.

Asare et al. [18] showed that only limited sources of resistance exist against $S$. gesnerioides in Ghanaian cowpea germplasm, and this underscores the need for more extensive analysis of breeding lines and exploitation of exotic genetic resources for cowpea improvement in Ghana. Some recombinant inbred lines (RILs) of cowpea, local cowpea accessions and exotic cowpea genotypes from the International Institute of Tropical Agriculture (IITA), exist in the Department of Molecular Biology and Biotechnology of the University of Cape Coast. However, these cowpea genotypes lack comprehensive assessment of their reactions to Striga infestation and genetic analysis which are necessary to facilitate selection and evaluation towards the release of adaptable cowpeas as varieties. The objective of the current study was to assess the reactions of 46 cowpea genotypes to $S$. gesnerioides infestation and to determine resistant genotypes.

\section{Materials and Methods}

A total of forty-six (46) cowpea genotypes were obtained from the Department of Molecular Biology and Biotechnology, University of Cape Coast. Twenty-eight (28) of the cowpea genotypes were recombinant inbred lines developed from a cross between IT97K-499-35 (resistant parent) and Apagbaala and SARC-LO2 (susceptible parents); fourteen (14) were cowpea genotypes from International Institute of Tropical Agriculture (IITA), Nigeria, the three parental genotypes (IT97K-499-35, Apagbaala, and SARC-LO2) as well as the local landrace, GH3684.

2.1. Pot Screening. The pot culture screening method used by $[5,17]$ was employed to assess the reaction of the cowpea genotypes to $S$. gesnerioides infestation. Each cowpea genotype was screened against Striga from Manga (upper east region), Lawra (upper west region), and Walewale (northern region). The test was conducted at the Manga Research Station of the Savannah Agricultural Research Institute (SARI) of the Council for Scientific and Industrial Research (CSIR) in Bawku. The potted soil medium was inoculated with Striga seeds, and four seeds of each cowpea genotype were sown per pot and replicated three times. The seedlings were thinned out at two weeks (14 days) after sowing and three plants were maintained per pot. The soil was kept moist by watering regularly every two days or when necessary. Hand picking of weeds was done when necessary. The days to emergence of Striga and the number of Striga per pot were recorded after 6 weeks. The plant-soil mass was removed from each pot and gently agitated to loosen the soil mass. The roots were washed thoroughly free of soil and examined using hand lens for the presence of necrotic hypersensitive lesions, attachment of $S$. gesnerioides, and tubercles. Cowpea plants that favoured attachment and emergence of $S$. gesnerioides were classified as susceptible and those that were intact and free from infestation, thus without any Striga attachment, were categorized as resistant.

\subsection{DNA Analysis}

2.2.1. DNA Extraction. The genomic DNA from each plant was fixed on FTA plant card (Bioneer) and processed as described by $[19,20]$, with slight modifications. Each isolated leaf from cowpea seedlings was cleaned with $70 \%$ ethanol and then placed over the marked circle with the underside of the leaf facing down on top of the FTA matrix card. The leaf was overlaid with parafilm, and a small porcelain pestle was used to apply moderate pounding over each sample circle area to burst the cell walls of the plant tissue. The back of the FTA card matrix was checked to observe the plant tissue extract drawn through the matrix. The FTA card was air-dried at room temperature for about one hour thirty minutes after the plant tissue extract transfer was completed. The FTA matrix card was placed on FTA sample mat and $2.0 \mathrm{~mm}$ Harris micro-punch tool was used to isolate several discs from the center of the dried sample area into $1.5 \mathrm{ml}$ microfuge tube. Alcohol was used to wipe the punch tip after picking samples from a particular cowpea genotype before being reused to pick samples from another cowpea genotype. The leaf discs in each tube were washed with $70 \%$ ethanol for 5 minutes and repeated until the disc turned white. About $200 \mu$ l of FTA purification reagent was added to each tube, capped, inverted twice, and incubated for 5 minutes at room temperature. The FTA reagent was pipetted up and down twice to ensure that the disc remained in the tube. A pipette was used to remove and discard the FTA purification reagent. This was repeated for two FTA reagent washes. The discs were allowed to completely air dry for a minimum of one hour at room temperature and stored at $4^{\circ} \mathrm{C}$ until being ready for PCR amplification.

2.2.2. Primer Screening. A total of 100 SSR primers were screened for polymorphism involving two cowpea parental genotypes, IT97K-499-35 and SARC-LO2, to ensure optimal 
performance. Optimal PCR amplification was achieved within the range of 55 to $60^{\circ} \mathrm{C}$ annealing temperatures. Sixteen SSR polymorphic primer pairs (Table 1) were selected and used for genetic analysis of the cowpeas.

2.3. Polymerase Chain Reaction (PCR) Analysis. AccuPower Taq PCR Premix containing Taq DNA Polymerase, dNTPs, reaction buffer, tracking dye, and patented stabilizer ordered from Bioneer was used in this work. $10 \mu \mathrm{l}$ of the complete PCR amplification mixture including $1 \mu \mathrm{l}$ of primer pair was added directly to the PCR tube containing the dried FTA disc. Each of the 16 primer pairs (Table 1) was used to amplify genomic DNA of the 46 cowpea genotypes. PCR amplification was carried out in Bio-Rad T100 ${ }^{\mathrm{TM}}$ thermal cycler (Applied Biosystems). PCR conditions involved denaturing at $94^{\circ} \mathrm{C}$ for 3 minutes, annealing at $55-60^{\circ} \mathrm{C}$ (Table 1) for each primer pair for 30 seconds, and extension at $72^{\circ} \mathrm{C}$ for 30 seconds. This cycle was repeated 35 times, with a final extension at $72^{\circ} \mathrm{C}$ for 10 minutes, and PCR products were stored at $4^{\circ} \mathrm{C}$.

2.3.1. Gel Electrophoresis. The $2 \%$ agarose gel was casted in a tray $(27.5 \mathrm{~cm} \times 24.5 \mathrm{~cm})$ with 15 -well-forming comb inserted to create wells. A $40 \mathrm{ml}$ agarose gel was prepared by dissolving $0.8 \mathrm{~g}$ of the agarose in $40 \mathrm{ml}$ of $\times 1$ TBE buffer in a microwave. The mixture was stained with $3.0 \mu \mathrm{l}$ ethidium bromide. The mixture was then poured into the tank and distributed across the whole surface and allowed to solidify. The whole assembly was transferred into electrophoretic tank after the comb was removed; the assembly was submerged in $\times 1$ TBE buffer. The PCR products were loaded into the wells. The lid of the electrophoresis tank was then fixed. The PCR products were resolved for $1 \mathrm{hr}$. at $120 \mathrm{~mA}$ and $90 \mathrm{~V}$ and visualized on a UV transilluminator (M-15; UVP, Upland, CA, USA). The DNA bands in the gel were photodocumented with a digital camera (Sony SELP1650, Thailand). The size of DNA bands in base pairs was determined using the $100 \mathrm{bp}$ DNA standard ladder (N0551S, Bioneer).

2.4. Data Analysis. Morphological and physiological data collected from the pot experiment were subjected to the Analysis of Variance (ANOVA) using General Statistics (Genstat) analytical software (version 12.1.0.3338). Varietal means were compared using the Least Significant Difference (LSD) at 5\% level of probability. The scoring and analysis of molecular data followed the format used by [21], with slight modifications. All genotypes were scored for the presence and absence of DNA bands. Only clear and repeatable polymorphic DNA bands were scored as " + " for presence of band associated with Striga-resistant and "-" for absence of band associated with Striga-susceptible. The $100 \mathrm{bp}$ standard ladder was used to determine the size of polymorphic DNA bands across the cowpea genome. Data matrix was created and used to calculate the genetic distance and similarity using PowerMarker V. 3.25. The related genetic parameters including the number of polymorphic bands, alleles per locus, genetic diversity, and polymorphism information content (PIC) are generated through the similarity matrixes for cluster analysis using PowerMarker V. 3.25. The Unweighted Pair Group Method with Arithmetic Mean (UPGMA) on the similarity indices was performed to identify genetic variation patterns among cowpea genotypes, and the resulting dendrogram generated was observed in MEGA 7 software.

\section{Results}

3.1. Phenotypic Screening. The 46 cowpea genotypes expressed resistance or susceptible responses across the spectrum of S. gesnerioides from Walewale (northern region), Manga (upper east region), and Lawra (upper west region). In all, 65.2\% (30) of the cowpea genotypes were resistant to S. gesnerioides and $34.8 \%$ (16) were susceptible (Table 2). The cowpea genotypes that expressed complete resistance to the "witchweed" in Ghana were not associated with the emergence of $S$. gesnerioides (Figure 1(b)), no attachment of $S$. gesnerioides to the roots, or necrotic hypersensitive lesions on the roots. Susceptible cowpea genotypes were characterized by an average of 15 emerged $S$. gesnerioides seedlings per pot (Figure 1(a)) and attachment of tubercles to the roots. The seedlings of germinated Striga emerged on the surface of the soil after 31 days (Table 3) of sowing. The Striga-infested cowpea plants expressed varied symptoms including stunted growth, leaf necrosis, chlorosis, senescence, defoliation and reduced size of young leaves, low flowering, and pod formation.

3.2. Molecular Screening. The amplicons of C42-2B marker across the genome of 46 cowpea genotypes appeared as single DNA bands of $280 \mathrm{bp}$, associated with resistant cowpea genotypes but that of 61R-M2 marker was expressed as double DNA bands of $320 \mathrm{bp}$ and $380 \mathrm{bp}$ associated with resistant cowpea genotypes. Susceptible cowpea genotypes showed only single DNA band of $380 \mathrm{bp}$ for $61 \mathrm{R}-\mathrm{M} 2$ or no band at all (Table 3 ).

3.3. SSR Polymorphism. The 16 informative SSR primers distinguished all the $46(100 \%)$ genotypes of the cowpea including those from same parents and those with similar seed size and seed coat colour. The sizes of polymorphic amplicons (DNA bands) ranged from $120 \mathrm{bp}$ for SSR-6315 to $750 \mathrm{bp}$ for SSR-6375. The number of alleles detected per primer pair varied from a minimum of 2 to a maximum of 22 with an average of 5.25. The allele frequencies yielded by the 16 SSR primers ranged from 0.57 to 0.98 with an average of 0.78 . Gene diversity also ranged from 0.04 to 0.49 with an average of 0.29 . The PIC varied from 0.08 to 1.00 with an average of 0.55 , from a total of 8.76 (Table 4 ). Fifty percent of the primers had PIC of 0.5 or above. There was significant $(P \leq 0.05)$ correlation between the allele frequency and the gene diversity. There was, however, no significant $(P \geq 0.05)$ correlation between the allele frequency and the PIC $(P$-value $=0.322 ; r=0.265)$ and between the gene diversity and PIC $(P$-value $=0.246 ; r=-0.308)$. 
TABLE 1: SSR primers used, their sequences, and annealing temperatures.

\begin{tabular}{|c|c|c|}
\hline Name & Sequence & Annealing temperature $\left({ }^{\circ} \mathrm{C}\right)$ \\
\hline SSR-6265 & $\begin{array}{l}\text { CAG AAG AGG TGA AAA TTG AAC } \\
\text { GCA TGT TGC TTT GAC AAT GGT }\end{array}$ & 57 \\
\hline SSR-6299 & $\begin{array}{l}\text { GGC GCA GAA AGA CAG GTT AC } \\
\text { CTG CAG CAC CTA ACT CAC CA }\end{array}$ & 60 \\
\hline SSR-6315 & $\begin{array}{l}\text { CGC AGT GAA AAG GAA AAG GA } \\
\text { ATC AGC GTC CAA TCC AAA AA }\end{array}$ & 55 \\
\hline SSR-6929 & $\begin{array}{l}\text { GCC CAT GTA ATG CTG TAT AGT } \\
\text { GGC GTT AGA ACT ACT CCA GTT }\end{array}$ & 57 \\
\hline SSR-6965 & $\begin{array}{l}\text { GCA TTC AGC TAC GAT GTG TTC } \\
\text { GGC ACT TTG TAA AAG ACA GGC }\end{array}$ & 59 \\
\hline SSR-6291 & $\begin{array}{l}\text { TCA TGA GTT TCC ACA CAC CAA } \\
\text { CCT TCG TAT GTA TAT GTG GCT ACT G }\end{array}$ & 60 \\
\hline SSR-6375 & $\begin{array}{l}\text { GCT CGG ATA TGG TCC TGA AA } \\
\text { TCA GTG TCA GCA CCA TAC CC }\end{array}$ & 60 \\
\hline SSR-6777 & $\begin{array}{c}\text { CGA AGC ATG TGG ACA CGT AC } \\
\text { CAT TGA ACA AAC ATC GCT GAA GC }\end{array}$ & 60 \\
\hline SSR-6273 & $\begin{array}{l}\text { CCC CCA GAA CAA ATA GAA ACT C } \\
\text { TGA ATT TGA AGA AGA GAT AAT TG }\end{array}$ & 60 \\
\hline SSR-6248 & $\begin{array}{c}\text { GGG TGC TTT GCT CAC ATC TT } \\
\text { TCC ATG TGT TTA TGA CGC AAA }\end{array}$ & 58 \\
\hline SSR-6171 & $\begin{array}{l}\text { ATT CGA TCC AAC CCA ATG AC } \\
\text { AGC GAA GGC ATG TTC GTA AG }\end{array}$ & 58 \\
\hline SSR-6235 & $\begin{array}{l}\text { TTT TCC CTC CAC CTG TTT GA } \\
\text { GAA GCA TTG ACC AAG CAA CA }\end{array}$ & 56 \\
\hline SSR-6243 & $\begin{array}{c}\text { GTA GGG AGT TGG CCA CGA TA } \\
\text { CAA CCG ATG TAA AAA GTG GAC A }\end{array}$ & 60 \\
\hline SSR-6260 & $\begin{array}{c}\text { AAA GTT TTA ATA TTA CCA ACA ACA A } \\
\text { CAA CCA GGC AAA TGG AAA TC }\end{array}$ & 56 \\
\hline SSR-6240 & $\begin{array}{l}\text { TTC AAT GTG GGA GGA TGA GA } \\
\text { GGT TCC GGA TTC AAT TTT CC }\end{array}$ & 56 \\
\hline $\mathrm{C} 42-2 \mathrm{~B}$ & $\begin{array}{l}\text { CAG TTC CCT AAT GGA CAA CC } \\
\text { CAA GCT CAT CATCAT CTC GAT G }\end{array}$ & 58 \\
\hline 61RM2 & $\begin{array}{l}\text { GAT TTG TTT GGT TTC CTT AAG } \\
\text { GGT TGA TCT TGG AGG CAT TTT }\end{array}$ & 57 \\
\hline
\end{tabular}

3.4. Cluster Analysis. Sixteen (16) polymorphic primers differentiated the 46 cowpea genotypes into three major clusters, A, B, and C, at 0.15 similarity coefficient (Figure 2). Cluster A was the largest comprising 26 cowpea genotypes, out of which 15 were inbred lines from the University of Cape Coast, 8 cowpea genotypes from IITA, and 3 local genotypes (GH3684, Apagbaala, and SARC-LO2). Sixteen of the cowpea genotypes in cluster A are Striga resistant and 10 are Striga susceptible.

Cluster B had 17 cowpea genotypes, out of which, 12 are Striga resistant and 5 are Striga susceptible. Cluster $\mathrm{C}$ was made up of only two cowpea genotypes (UCC-122 and UCC-24) which are both Striga resistant. SARC-LO2 and Apagbaala, as well as UCC-497 and UCC-514, were the most genetically similar with a genetic distance of $0.05 \mathrm{cM}$. The longest genetic distance $(0.50 \mathrm{cM})$ existed between UCC-11 and UCC-24, UCC-11 and UCC-523, and UCC-32 and UCC-473.

The 30 Striga-resistant genotypes were spread throughout the spectrum of the three clusters. Generally, they were diverse, with only a few of them closely related. UCC-241 and UCC-428, IT10K-499-35 and UCC-478, and IT08K-150-12 and IT10K-817-3 were the most closely related with a genetic distance of $0.07 \mathrm{cM}$. UCC-11 and UCC-
24 and UCC-32 and UCC-473, which are all Striga-resistant genotypes, showed the highest diversity among the 30 Strigaresistant genotypes with a genetic distance of $0.50 \mathrm{cM}$. Ten (10) out of the fifteen Striga-susceptible cowpea genotypes were clustered together (Cluster A). They were, however, not closely related, with the exception of Apagbaala and SARCLO2 and IT10K-125-107 and UCC-white with genetic distances of $0.05 \mathrm{cM}$ and $0.08 \mathrm{cM}$, respectively.

\section{Discussion}

4.1. Phenotypic Analysis. The overall resistance or susceptibility expressed by the 46 cowpea genotypes to the $S$. gesnerioides from Walewale (northern region), Manga (upper east region), and Lawra (upper west region) gave implication that probably the S. gesnerioides samples may be of the same race or the cowpea genotypes may have multiple resistance to the parasitic weed in Ghana. Indeed, [18] observed similar responses to S. gesnerioides from Bawku among recombinant inbred lines (RILs) of cowpea. This suggests that the Ghanaian biotypes of S. gesnerioides may have similar virulence [5]. Besides, the Striga-resistant cowpeas may possess the Striga-race-specific resistant gene 
TABle 2: The responses of cowpea genotypes to S. gesnerioides infestation.

\begin{tabular}{|c|c|c|c|c|c|}
\hline \multirow{2}{*}{ Genotype } & \multicolumn{3}{|c|}{ Phenotype } & \multicolumn{2}{|c|}{ Genotype } \\
\hline & Manga & Lawra & Walewale & $\mathrm{C} 42-2 \mathrm{~B}$ & 61R-M2 \\
\hline UCC-11 & $\mathrm{R}$ & $\mathrm{R}$ & $\mathrm{R}$ & + & - \\
\hline UCC-24 & $\mathrm{R}$ & $\mathrm{R}$ & $\mathrm{R}$ & + & + \\
\hline UCC-32 & $\mathrm{R}$ & $\mathrm{R}$ & $\mathrm{R}$ & + & + \\
\hline UCC-56 & $S$ & $S$ & $S$ & + & + \\
\hline UCC-122 & $\mathrm{R}$ & $\mathrm{R}$ & $\mathrm{R}$ & + & + \\
\hline UCC-153 & $\mathrm{R}$ & $\mathrm{R}$ & $\mathrm{R}$ & + & + \\
\hline UCC-221 & $\mathrm{R}$ & $\mathrm{R}$ & $\mathrm{R}$ & + & + \\
\hline UCC-226 & $\mathrm{R}$ & $\mathrm{R}$ & $\mathrm{R}$ & + & - \\
\hline UCC-241 & $\mathrm{R}$ & $\mathrm{R}$ & $\mathrm{R}$ & + & + \\
\hline UCC-328 & $\mathrm{R}$ & $\mathrm{R}$ & $\mathrm{R}$ & + & - \\
\hline UCC-366 & $\mathrm{S}$ & $\mathrm{S}$ & $\mathrm{S}$ & + & - \\
\hline UCC-445 & $\mathrm{R}$ & $\mathrm{R}$ & $\mathrm{R}$ & + & - \\
\hline UCC-460 & $\mathrm{R}$ & $\mathrm{R}$ & $\mathrm{R}$ & + & + \\
\hline UCC-466 & $\mathrm{R}$ & $\mathrm{R}$ & $\mathrm{R}$ & + & + \\
\hline UCC-471 & $\mathrm{R}$ & $\mathrm{R}$ & $\mathrm{R}$ & + & + \\
\hline UCC-478 & $\mathrm{R}$ & $\mathrm{R}$ & $\mathrm{R}$ & + & + \\
\hline UCC-484 & $\mathrm{R}$ & $\mathrm{R}$ & $\mathrm{R}$ & - & - \\
\hline UCC-489 & $S$ & $S$ & $S$ & + & + \\
\hline UCC-490 & $S$ & S & $S$ & - & + \\
\hline UCC-497 & $S$ & $S$ & $S$ & - & + \\
\hline UCC-513 & $\mathrm{R}$ & $\mathrm{R}$ & $\mathrm{R}$ & + & + \\
\hline UCC-514 & $S$ & $S$ & $\mathrm{~S}$ & - & + \\
\hline UCC-523 & $S$ & $S$ & $S$ & - & + \\
\hline UCC- 428 & $\mathrm{R}$ & $\mathrm{R}$ & $\mathrm{R}$ & + & + \\
\hline UCC-473 & $\mathrm{R}$ & $\mathrm{R}$ & $\mathrm{R}$ & - & - \\
\hline UCC-377 & $\mathrm{R}$ & $\mathrm{R}$ & $\mathrm{R}$ & + & - \\
\hline GH3684 & $\mathrm{R}$ & $\mathrm{R}$ & $\mathrm{R}$ & + & - \\
\hline UCC-White & $S$ & $S$ & $\mathrm{~S}$ & - & - \\
\hline UCC-Early & $S$ & $S$ & $S$ & - & - \\
\hline IT97K-499-35 & $\mathrm{R}$ & $\mathrm{R}$ & $\mathrm{R}$ & + & + \\
\hline SARC-LO2 & S & S & S & - & - \\
\hline Apagbaala & $\mathrm{S}$ & $\mathrm{S}$ & $\mathrm{S}$ & - & - \\
\hline IT08K-193-14 & $\mathrm{R}$ & $\mathrm{R}$ & $\mathrm{R}$ & - & - \\
\hline IT10K-815-5 & S & S & S & + & - \\
\hline IT10K-125-107 & $\mathrm{R}$ & $\mathrm{R}$ & $\mathrm{R}$ & - & + \\
\hline IT10K-832-3 & $\mathrm{R}$ & $\mathrm{R}$ & $\mathrm{R}$ & + & + \\
\hline IT10K-456 & $\mathrm{R}$ & $\mathrm{R}$ & $\mathrm{R}$ & + & - \\
\hline IT10K-298-9 & S & S & S & - & - \\
\hline IT07K-297-13 & S & $S$ & S & + & + \\
\hline IT08K-150-12 & $\mathrm{R}$ & $\mathrm{R}$ & $\mathrm{R}$ & + & - \\
\hline IT08K-126-19 & $\mathrm{R}$ & $\mathrm{R}$ & $\mathrm{R}$ & + & + \\
\hline IT08K-193-15 & $\mathrm{R}$ & $\mathrm{R}$ & $\mathrm{R}$ & - & + \\
\hline IT11K-61-82 & $S$ & $\mathrm{~S}$ & $\mathrm{~S}$ & - & + \\
\hline IT11K-321-2 & S & $\mathrm{S}$ & $\mathrm{S}$ & + & + \\
\hline IT10K-817-3 & $\mathrm{R}$ & $\mathrm{R}$ & $\mathrm{R}$ & + & - \\
\hline IT10K-819-4 & $\mathrm{R}$ & $\mathrm{R}$ & $\mathrm{R}$ & + & + \\
\hline
\end{tabular}

R: resistant, $\mathrm{S}$ : susceptible, + : presence of marker, and -: absence of marker.

to combat the Ghanaian isolate of the parasite. In addition, the cowpeas genotypes from IITA and the local landrace GH3684 may have similar Striga-resistant trait as IT97K499-35. The Striga-resistant cowpeas in the current study showed robust and healthy growth forms compared to the Striga-susceptible cowpeas (Figure 1). The enhanced vigorous growth of Striga-resistant cowpea genotypes may be due to adequate biomass accumulation [22] that could be translated into grain yield contrary to the Striga-susceptible cowpeas.
4.2. Molecular Analysis. The resistance status of the cowpea genotypes to S. gesnerioides was validated with C42-2B and 61R-M2 markers. The results are consistent with those of Asare et al. [18], who used C42-2B to screen some breeding lines of cowpea. The marker segregation efficiency of $83.3 \%$ for $\mathrm{C} 42-2 \mathrm{~B}$ was better than that of $60 \%$ for $61 \mathrm{R}-\mathrm{M} 2$ in identifying Striga-resistant cowpea genotypes. However, 92.6\% discriminatory efficiency of SSR-1 marker was reported among cowpea breeding population [18].

The cowpea genotypes UCC-11, UCC-24', UCC-56, UCC-122, UCC-221, UCC-226, UCC-241, and UCC-328 had stable resistance to S. gesnerioides. The stability of resistance to $S$. gesnerioides demonstrated by the cowpeas suggests that the Striga-resistant gene might be fixed in the $\mathrm{F}_{9}$ recombinant inbred lines.

The current study observed double DNA bands of $380 \mathrm{bp}$ and $320 \mathrm{bp}$ for the 61R-M2 marker associated with $S$. gesnerioides-resistant cowpea genotypes. This was consistent with the similar result by Omoigui et al. [23], who also observed the double DNA band characteristic of 61R-M2 marker in Striga-resistant cowpea genome of $F_{1}$ and $F_{2}$ populations from a cross between Borno Brown $\times$ IT97K499-35 and Borno Brown $\times$ B301. Four of the cowpea genotypes (UCC-56, UCC-489, IT07K-297-13, and IT11K321-2) had the C42-2B and 61R-M2 markers but were susceptible against $S$. gesnerioides in the pot analysis. However, three cowpea genotypes (UCC-473, UCC-484, and IT08K-193-14) were resistant to the sampled S. gesnerioides but did not amplify for any of the markers (Table 2). Unlike SSR-1 primer where the marker is within the Striga race 3 (SG3) gene of $\mathrm{B} 301(1 \mathrm{cM})$, the C42-2B and 61RM2 primers have their markers close to the resistant gene, with genetic distances of $8.5 \mathrm{cM}$ and $3.5 \mathrm{cM}$, respectively [23]. The Striga-resistant gene can be separated from the marker during crossover. The marker could, therefore, be present, but the gene controlling the resistance to $S$. gesnerioides may be absent. This could account for the reason why some of the cowpea genotypes (UCC-56, UCC-489, IT07K-297-13, and IT11K-321-2) had the marker of both primers present but susceptible phenotypically.

4.3. Genetic Analysis. The genetic diversity and phylogenetic relationships of cowpea genotypes from Ghana have been evaluated using SSR markers [24, 25]. In this study, all the 16 SSR primer combinations used gave amplification products with $100 \%$ polymorphism. The 16 selected microsatellites (SSR) markers differentiated the cowpea genotypes and clustered them differently. There was increasing similarity among the cowpea genotypes from IITA and the inbred lines from UCC. SARC-LO2 and Apagbaala, as well as UCC-497 and UCC-514, were the most genetically similar with a genetic distance of 0.0476 . The longest genetic distance $(0.500)$ existed between UCC-11 and UCC-24; UCC-11 and UCC-532; and UCC-32 and UCC-473. UCC-11, UCC-24, and UCC-32 are progenies from a cross between IT97K-499-35 × SARC-LO2, while UCC-473 and UCC-532 are progenies from a cross between IT97K-499-35 × Apagbaala. Most of the cowpea genotypes are also populations from the cross between IT97K- 

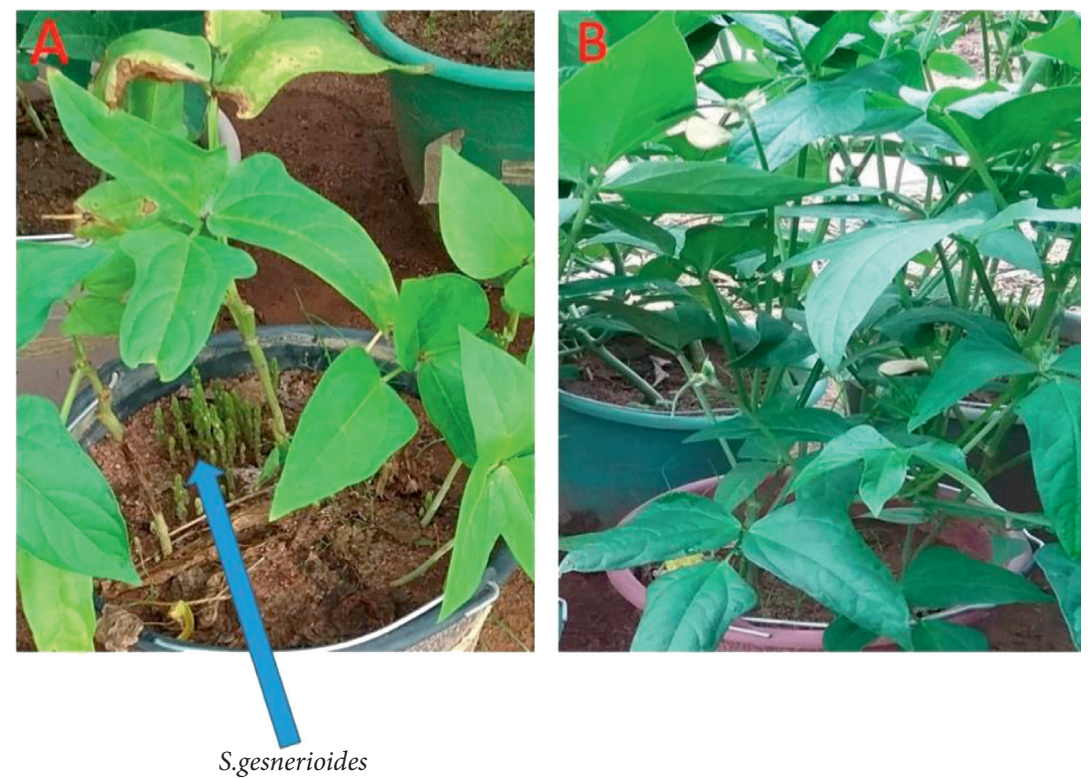

Figure 1: Response of cowpea plants to S. gesnerioides infestation at 5 weeks after sowing seeds in Striga-infested soil. (a) Striga-susceptible cowpea plants under stress by Striga seedlings parasitism. (b) Striga-resistant cowpea plants showing vigorous vegetative growth without Striga emergence.

TABle 3: Striga count per pot and days to emergence of Striga.

\begin{tabular}{|c|c|c|c|c|c|c|}
\hline \multirow[t]{2}{*}{ Genotypes } & \multicolumn{3}{|c|}{$\begin{array}{l}\text { Number of Striga } \\
\text { seedlings per pot }\end{array}$} & \multicolumn{3}{|c|}{$\begin{array}{l}\text { Days to Striga } \\
\text { emergence }\end{array}$} \\
\hline & M & $\mathrm{W}$ & $\mathrm{L}$ & M & W & $\mathrm{L}$ \\
\hline I0T1 & 10.67 & 7.00 & 12.00 & 39.67 & 34.33 & 34.30 \\
\hline IT07K-2 & 67 & 7.67 & 13. & 5.00 & 3 & 33.00 \\
\hline UCC-4 & 16.67 & 3 & 11. & .00 & & 3.60 \\
\hline IT11K-3 & 30.33 & & 20 & 36.00 & & 3.30 \\
\hline APAG & 12.00 & 2 & 15. & 32.00 & & 33.00 \\
\hline UCC-514 & 15.33 & 12.67 & 3.3 & 32.00 & 33. & 31.67 \\
\hline UCC & 0 & 1 & 7.3 & 32.00 & 33. & 31.33 \\
\hline UCC & .33 & 11.33 & 14.33 & 31.00 & 3 & 34.33 \\
\hline UCC-4 & 25.33 & 21.00 & 1.33 & 34.00 & 33. & 33.00 \\
\hline UCC-W & 27.33 & 23.33 & 16.0 & 34.00 & & 33.00 \\
\hline IT11 & 24.00 & 17. & 21. & 33.00 & 34. & 32.67 \\
\hline UCC-36 & 17.67 & 13.33 & 23.67 & 34.33 & 34.00 & 40.33 \\
\hline IT10K-815 & 10.67 & 8.3 & 5.67 & 49.33 & 33.33 & 33.67 \\
\hline & & 20. & 9.6 & 34.00 & & 33.67 \\
\hline UCC-Early & 22.00 & 24.00 & 20.33 & 34.00 & 34.67 & 35.33 \\
\hline
\end{tabular}

499-35 $\times$ SARC-LO2 and IT97K-499-35 $\times$ Apagbaala and therefore may share similar genetic traits. The common donor, IT97K-499-35, could influence the genetic relationship among the cowpea inbred lines in particular.

The genetic diversity across the cowpea genome in the current study is low. This was in line with a similar report by Asare et al. [24], who also observed a lower level of genetic variability among Ghanaian cowpea accessions. Kuruma et al. [26] also found low level of genetic diversity among cowpea accessions in Kenya using molecular markers. The low genetic diversity among the cowpea genotypes could be as a result of common ancestral origin and self-pollination mechanism in cowpea. The number of alleles per locus of 2 to 22 with an average of 5.25 detected in the current study is
Table 4: Number of alleles, gene diversity, and polymorphism information content for 16 primers used.

\begin{tabular}{lccccc}
\hline Primers & $\begin{array}{c}\text { Sample } \\
\text { size }\end{array}$ & $\begin{array}{c}\text { Number } \\
\text { of alleles }\end{array}$ & $\begin{array}{c}\text { Allele } \\
\text { frequency }\end{array}$ & $\begin{array}{c}\text { Gene } \\
\text { diversity }\end{array}$ & PIC \\
\hline SSR-6299 & 46.00 & 8.00 & 0.83 & 0.22 & 0.81 \\
C42-2B & 46.00 & 2.00 & 0.65 & 0.45 & 0.35 \\
61RM2 & 46.00 & 4.00 & 0.59 & 0.48 & 0.73 \\
SSR-6777 & 46.00 & 2.00 & 0.57 & 0.49 & 0.37 \\
SSR-6375 & 46.00 & 22.00 & 0.79 & 0.30 & 0.23 \\
SSR-6315 & 46.00 & 2.00 & 0.95 & 0.08 & 0.08 \\
SSR-6569 & 46.00 & 2.00 & 0.70 & 0.42 & 0.33 \\
SSR-6240 & 46.00 & 2.00 & 0.91 & 0.16 & 0.15 \\
SSR-6243 & 46.00 & 4.00 & 0.75 & 0.37 & 0.82 \\
SSR-6929 & 46.00 & 2.00 & 0.61 & 0.48 & 0.36 \\
SSR-6273 & 46.00 & 2.00 & 0.65 & 0.45 & 0.35 \\
SSR-6265 & 46.00 & 6.00 & 0.88 & 0.19 & 0.70 \\
SSR-6248 & 46.00 & 4.00 & 0.77 & 0.27 & 0.86 \\
SSR-6171 & 46.00 & 6.00 & 0.98 & 0.04 & 0.99 \\
SSR-6235 & 46.00 & 4.00 & 0.98 & 0.04 & 1.00 \\
SSR-6291 & 46.00 & 12.00 & 0.80 & 0.27 & 0.63 \\
Mean & 46.00 & 5.15 & 0.78 & 0.29 & 0.55 \\
\hline
\end{tabular}

$\mathrm{PIC}=$ polymorphism information content.

in line with other recent reports. Li et al. [27] assessed the genetic similarities and relationships among 48 wild cowpea lines using SSR primers and detected between 4 and 13 alleles with an average of 7.5 alleles. Indeed, the authors in [28] observed that the number of alleles ranged from 1 to 9 per SSR primer combination in cowpea germplasm from Senegal. Sawadogo et al. [29] indicated that the 16 SSR primers used to assess the genetic diversity of cowpea cultivar in Burkina Faso generated a range of alleles between 5 and 12 fragments with an average of 8.2 bands per primer combination among cowpea genotypes. A combination of 25 


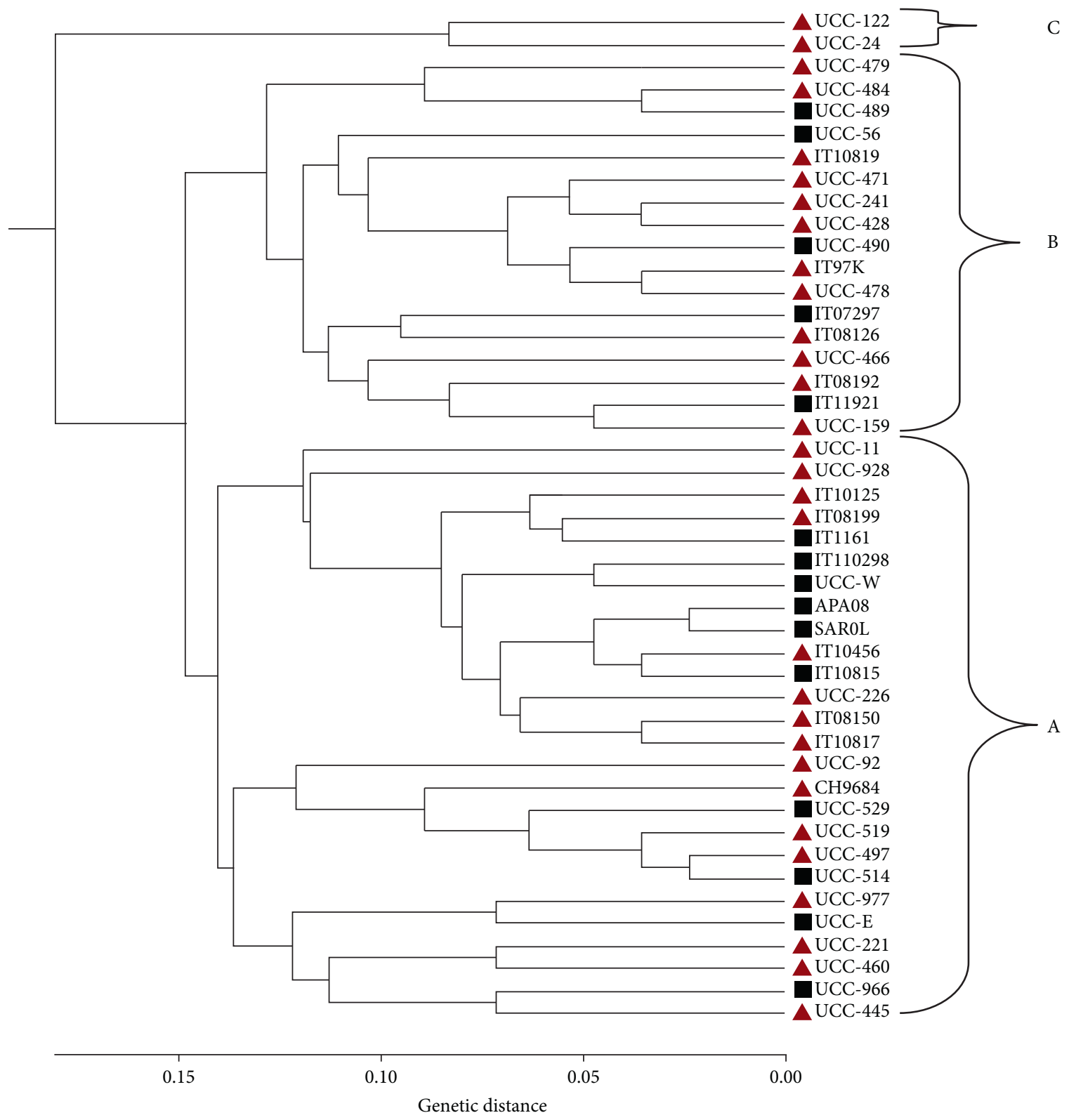

FIGURE 2: Phylogenetic relationship among 46 cowpea genotypes. A dendrogram was generated using sixteen informative SSR markers and sequential clustering algorithm (UPGMA) based on genetic similarity. UCC $-\mathrm{E}=\mathrm{UCC}-$ Early; UCC $-\mathrm{W}=\mathrm{UCC}-\mathrm{White}$; APAGB = Apagbaala; SARCL = SARC - LO2; IT97K = IT97K - 499-35; $\mathbf{\Delta}=$ Striga-resistant; and $\mathbf{\square}=$ Striga-susceptible.

informative SSR primers were used to analyse Ghanaian cowpea germplasm and yielded 1 to 6 alleles per primer pair with a mean of 3.8 [24]. The assessment of 48 accessions of cultivated cowpea sampled from West Africa, Northeast Africa, Central Africa, and Southern Africa using 12 SSR markers revealed that the number of alleles per locus ranged from 2 to 5 with a total of 37 alleles generated for the primers [30].

The polymorphism information content (PIC) is a means of detecting alleles and distribution of their frequencies [31]. Data reported by [24] showed PIC ranging between 0.07 and 0.66 with a mean of 0.38 . Sixteen SSR primers used to assess the genetic diversity and phylogenetic relationship among 252 cowpea genotypes in Sudan, yielding PIC between 0.33 and 0.83 with an average of 0.56 [31]. Genetic diversity studies among 32 cultivating cowpea, using 22 SSR primers, showed a PIC range from 0.25 to 0.63 with an average of 0.45 [21]. The mean PIC value (0.55) recorded in the current study is, therefore, in line with the results obtained from previous reports. The study in [30] produced a PIC valve ranging from 0.08 to 0.60 with a mean valve of 0.34 from a total of 4.47. Also, Larweh et al. [32] noted that polymorphism information content (PIC) values ranged from 0.32 to 0.36 with a mean of 0.34 in cowpea breeding lines. Ali et al. [33] reported that a mean PIC value $\geq 0.5$ is highly informative, $0.25 \sim 0.50$ reasonably informative, and $<0.25$ slightly informative, and loci (marker) with many alleles and a PIC value near 1 are most desirable. 
This means that the primers used for the current study were highly informative. Gene diversity observed in this study was 0.29 on average ranging from 0.04 to 0.49 . In Senegal, cowpea gene diversity varied from 0.08 to 0.42 with a mean of 0.28 [34], whereas in Ghana cowpea germplasm gene diversity ranged from 0.12 to 0.68 with an average of 0.44 [24]. The results of gene diversity reflect the proportion of polymorphic loci across the genome. Therefore, according to the result of the current study, the markers used were almost as polymorphic as those used by $[24,34]$.

\section{Conclusion}

The responses of 46 cowpea genotypes to $S$. gesnerioides samples from upper east (Manga), upper west (Lawra), and northern regions (Walewale) of Ghana were similar which implies that the S. gesnerioides in Ghana may be of the same biotype or the cowpea genotypes may have the same response to different races of $S$. gesnerioides. On the whole, $65.2 \%$ of the cowpea genotypes were resistant to $S$. gesnerioides associated with $\mathrm{C} 42-2 \mathrm{~B}$ and 61R-M2 markers and $34.8 \%$ were susceptible. The segregation efficiency of $80 \%$ of C42-2B marker (single DNA band of $280 \mathrm{bp}$ ) was better than that of $60 \%$ of $61 \mathrm{R}-\mathrm{M} 2$ (double DNA bands of $320 \mathrm{bp}$ and $380 \mathrm{bp}$ ) for identification of Striga-resistant cowpea genotypes. The 16 SSR primers were informative and could distinguish all the 46 cowpea genotypes into three major clusters in a dendrogram. The allele frequencies yielded by the SSR primers ranged from 0.57 to 0.98 with an average of 0.78 . Gene diversity also ranged from 0.04 to 0.49 with an average of 0.29 . The PIC varied from 0.08 to 1.00 with an average of 0.55 with a mean genetic diversity of 0.29 .

\section{Data Availability}

The data used to support the findings of this study can be accessed from the corresponding author upon request.

\section{Disclosure}

The authors take full responsibility for any error.

\section{Conflicts of Interest}

The authors declare that they have no conflicts of interest regarding the publication of this paper.

\section{Acknowledgments}

The authors are grateful to the International Treaty on Plant Genetic Resources for Food and Agriculture (ITPGRFA) and the Food and Agriculture Organization (FAO) for sponsoring this research.

\section{References}

[1] K. F. Egbadzor, M. Yeboah, S. K. Offei, K. Ofori, and E. Y. Danquah, "Farmers' key production constraints and traits desired in cowpea in Ghana," Journal of Agricultural Extension and Rural Development, vol. 5, no. 1, pp. 14-20, 2013.
[2] International Crops Research Institute for the Semi-Arid Tropics (ICRISAT), "Grain legume value chain alliance leveraging legumes to combat poverty, hunger, malnutrition and environmental degradation," in A CGIAR Research Programme Submitted by International Crops Research Institute for the Semi-arid Tropics (ICRISAT), CIAT, ICARDA and IITA to the CGIAR Consortium Board, International Crops Research Institute for the Semi-Arid Tropics, ICRISAT, Hyderabad, India, 2012.

[3] Ministry of Food and Agriculture (MoFA), Agriculture in Ghana, Facts and Figure, PPME: Statistics, Research and Information Directorate (SRID), Accra, Ministry of Food and Agriculture (MoFA), Accra, Ghana, 2010.

[4] M. P. Timko and B. B. Singh, Cowpea, a Multifunctional Legume: Genomics of Tropical Crop Plant, P. H. Moore and R. Ming, Eds., Springer, New York, NY, USA, 2008.

[5] T. A. Asare, I. K. A. Galyuon, F. K. Padi, E. P. Otwe, and J. F. Takarama, "Responses of recombinant inbred lines of cowpea [(Vigna unguiculata (L.) to Striga gesnerioides infestation in Ghana," in Proceedings of 1st Annual International Interdisciplinary Comference, AIIC 2013, pp. 24-26, Azore, Portugal, April 2013.

[6] C. Koga, S. Mabasa, U. Mazarura, D. Garwe, and D. Rukuni, "First reports of tobacco witch weed (Striga gesnerioides) parasitizing Dalbergia melanoxylon and Richardia scabra in Zimbabwe," Advances in Crop Science Tech, vol. 5, no. 5, p. 311, 2017.

[7] C. Koga, S. Mabasa, U. Mazarura, T. Banwa, and D. Garwe, "Screening of tobacco genotypes for tolerance/resistance to Striga gesnerioides infestation in Zimbabwe," Advances in Crop Science and Tech, vol. 6, no. 1, p. 340, 2018.

[8] K. F. Cardwell and J. A. Lane, "Effect of soils, cropping system and host phenotype on incidence and severity of Striga gesnerioides on cowpea in West Africa," Agriculture, Ecosystems \& Environment, vol. 53, no. 3, pp. 253-262, 1995.

[9] S. Müller, C. Hauck, and H. Schildknecht, "Germination stimulants produced by vigna unguiculata walp cv saunders upright," Journal of Plant Growth Regulation, vol. 11, no. 2, pp. 77-84, 1992.

[10] G. Reiss and J. A. Bailey, "Striga gesnerioides parasitising cowpea: development of infection structures and mechanisms of penetration," Annals of Botany, vol. 81, no. 3, pp. 431-440, 1998.

[11] F. S. Ba, R. S. Pasquet, and P. Gepts, "Genetic diversity in cowpea [Vigna unguiculata (L.) Walp.] as revealed by RAPD markers," Genetic Resources and Crop Evolution, vol. 51, no. 5, pp. 539-550, 2004.

[12] J. D. Graves, M. C. Press, S. Smith, and G. R. Stewart, “The carbon canopy economy of the association between cowpea and the parasitic angiosperm Striga gesnerioides," Plant, Cell and Environment, vol. 15, no. 3, pp. 283-288, 1992.

[13] O. K. Berner, J. G. Kling, and B. B. Singh, "Striga research and control: a perspective from Africa," Plant Disease, vol. 79, no. 7, pp. 652-660, 1995.

[14] J.-B. N. Tchiagam, J. M. Bell, S. G. Birwe, S. Gonne, and E. Youmbi, "Varietal response of cowpea (Vigna unguiculata (L.) walp.) to Striga gesnerioides (willd.) Vatke race SG5 infestation," Notulae Botanicae Horti AgrobotaniciCluj-Napoca, vol. 38, no. 2, pp. 33-41, 2010.

[15] L. O. Omoigui, A. Y. Kamara, F. S. Massawe et al., "Evaluation of cowpea genotypes for their reaction to Striga gesnerioides in the dry Savanna of Northeast Nigeria," African Crop Science Conference Proceedings, vol. 8, no. 3, pp. 273-278, 2007. 
[16] J. A. Lane, T. H. M. Moore, D. V. Child, and K. F. Cardwell, "Characterization of virulence and geographic distribution of Striga gesnerioideson cowpea in West Africa," Plant Disease, vol. 80, no. 3, pp. 299-301, 1996.

[17] C. J. Botanga and M. P. Timko, "Genetic structure and analysis of host and nonhost interactions of Striga gesnerioides (witchweed) from central Florida," Phytopathology, vol. 95, no. 10, pp. 1166-1173, 2005.

[18] A. T. Asare, B. S. Gowda, I. K. A. Galyuon et al., "Identification of potential sources of striga resistance in cowpea [Vigna Unguiculata (L.) walp.] accessions from Ghana," Journal of Microbiology and Biotechnology Research, vol. 3, no. 1, pp. 14-22, 2013.

[19] L. O. Omoigui, A. Y. Kamara, M. F. Ishiyaku, and O. Bonkar, "Comparative responses of cowpea breeding lines to Striga and Alectra in the dry Savanna of Northeast Nigeria," African Journal of Agricultural Resources, vol. 7, no. 5, pp. 747-754, 2012.

[20] F. Kusi, "Deployment of the Cowpea Aphid resistance gene for Cowpea improvement in Ghana," Ph.D. thesis, University of Ghana, Legon, Ghana, 2014, http://ugspace.ug.edu.gh.

[21] M. Khosro, R. B. Mohammad, and R. A. Ali, "Assessment of genetic diversity in cowpea (Vigna unguiculata L.) germplasm using morphological and molecular characterization," Cogent Food and Agriculture, vol. 3, no. 1, Article ID 1327092, 2017.

[22] S. O. Alonge, S. T. O. Lagoke, and C. O. Ajakaiye, "Cowpea reactions to Striga gesnerioides I. effect on growth," Crop Protection, vol. 24, no. 6, pp. 565-573, 2005.

[23] L. O. Omoigui, M. F. Ishiyaku, B. S. Gowda, A. Y. Kamara, and M. P. Timko, "Suitability and use of two molecular markers to track race-specific resistance Striga gesnerioides in cowpea (Vigna unguiculata (L.) Walp.)," African Journal of Biotechnology, vol. 14, no. 27, pp. 2180-2090, 2015.

[24] A. T. Asare, B. S. Gowda, I. K. A. Galyuon, L. L. Aboagye, J. F. Takrama, and M. P. Timko, "Assessment of the genetic diversity in cowpea (Vigna unguiculata L. Walp.) germplasm from Ghana using simple sequence repeat markers," Plant Genetic Resources: Characterization and Utilization, vol. 8, no. 2, pp. 1-9, 2010.

[25] I. Z. Doumbia, R. Akromah, and J. Y. Asibuo, “Assessment of cowpea germplasms from Ghana and Mali using simple sequence repeat (SSR) markers," International Journal of Agriculture and Forestry, vol. 4, no. 2, pp. 118-123, 2014

[26] R. W. Kuruma, O. Kiplagat, E. Ateka, and G. Owuoche, "Genetic diversity of Kenyan cowpea accessions based on morphological and microsatellite markers," East African Agricultural and Forestry Journal, vol. 76, pp. 3-4, 2008.

[27] C. D. Li, C. A. Fatokun, B. Ubi, B. B. Singh, and G. J. Scoles, "Determining genetic similarities and relationships among cowpea breeding lines and cultivars by microsatellite markers," Crop Science, vol. 41, no. 1, pp. 189-197, 2001.

[28] D. Diouf and K. W. Hilu, "Microsatellites and RAPD markers to study genetic relationships among cowpea breeding lines and local varieties in Senegal," Genetic Resources and Crop Evolution, vol. 52, no. 8, pp. 1057-1067, 2005.

[29] M. Sawadogo, J. T. Ouedraogo, B. S. Gowda, and M. P. Timko, "Genetic diversity of cowpea (Vigna unguiculata L. Walp) cultivars in Burkina Faso resistant to Striga gesnerioides," African Journal of Biotechnology, vol. 9, no. 48, pp. 8146-8153, 2010.

[30] L. A. Ogunkanmi, O. T. Ogundipe, and C. A. Fatokun, "Molecular characterization of cultivated cowpea (Vigna unguiculata L. Walp) using simple sequence repeats markers,"
African Journal of Biotechnology, vol. 13, no. 34, pp. 34643472, 2014.

[31] M. Moghaddam, S. A. Mohammmadi, N. Mohebalipour, M. Toorchi, S. Aharizad, and F. Javidfar, "Assessment of genetic diversity in rape seed cultivars as revealed by RAPD and microsatellite markers," African Journal of Biotechnology, vol. 8, pp. 3160-3167, 2009.

[32] V. Larweh, S. Akromah, R. Akromah et al., "Marker assisted selection for resistance to Striga gesnerioides in cowpea (Vigna unguiculata L. Walp)," Journal of Bioscience and Biotechnology Discovery, vol. 2, no. 5, pp. 97-103, 2017.

[33] Z. B. Ali, K. N. Yao, D. A. Odeny, M. Kyalo, R. Skilton, and I. M. Eltahir, "Assessing the genetic diversity of cowpea [Vigna unguiculata (L.) Walp.] accessions from Sudan using simple sequence repeat (SSR) markers," African Journal of Plant Science, vol. 9, no. 7, pp. 293-304, 2015.

[34] F. A. Badiane, B. S. Gowda, N. Cissé, D. Diouf, O. Sadio, and M. P. Timko, "Genetic relationship of cowpea (Vigna unguiculata) varieties from senegal based on SSR markers," Genetics and Molecular Research ISSN, vol. 11, no. 1, pp. 1676-5680, 2012. 